December 2017

\title{
La Revolte des Prostituées/The Sex Workers Revolt: a dual analysis
}

Sean Prpick

formerly Canadian Broadcasting Corporation

Maud Beaulieu

formerly Canadian Broadcasting Corporation

Follow this and additional works at: http://ro.uow.edu.au/rdr

Part of the Audio Arts and Acoustics Commons, Digital Humanities Commons, Feminist, Gender, and Sexuality Studies Commons, and the Radio Commons

\section{Recommended Citation}

Prpick, Sean and Beaulieu, Maud, La Revolte des Prostituées/The Sex Workers Revolt: a dual analysis, RadioDoc Review, 3(2), 2017.

Research Online is the open access institutional repository for the University of Wollongong. For further information contact the UOW Library: research-pubs@uow.edu.au 


\title{
La Revolte des Prostituées/The Sex Workers Revolt: a dual analysis
}

\begin{abstract}
This documentary chronicles how hundreds of French sex workers went on strike in 1975 and occupied five Catholic churches to protest against police abuse and government closure of their workplace. Forty years on, Australian producer, academic and sex worker rights researcher Eurydice Aroney revisits the Lyon cathedral occupied by the women with the full blessing of its cleric, Père Blanc, now ninety years old. Interviews with Blanc and some of the original sex worker protesters are interwoven with archival material to make a compelling audio story, selected as a finalist for the UK In The Dark award (2015).

This work has had several incarnations: the original 50-minute French documentary heard on Radio France Culture and Radio Belgium; the French documentary watched with English subtitles provided by the In the Dark organisation; and a shorter (27mins) remixed English version, heard on ABC RN's Earshot. To address these complexities, RadioDoc Review asked former CBC broadcasters Sean Prpick and Maud Beaulieu to review the work from different perspectives: Prprick, as an English-speaking producer, listened to the subtitled French and the English versions; Beaulieu, who is bilingual, evaluated the original French version using guidelines devised by the RDR Editorial Board. Finally, RDR Editor interviews producer Eurydice Aroney about the complexities of making a crosscultural work on a politically delicate theme and its standing as an academic research publication, known as a Non-Traditional Research Output (NTRO).
\end{abstract}

\section{Keywords}

radio documentary, audio feature, podcast, sex workers, sex workers rights 


\title{
La Revolte des Prostituées/The Sex Workers Revolt: a dual analysis
}

\section{Reviewed by Sean Prpick and Maud Beaulieu}

\author{
La Revolte des Prostituées/The Prostitutes' Revolt \\ Original documentary broadcast June 2015 by Radio France Culture and \\ Radio Belgium. Duration: 50'35". \\ Produced by Eurydice Aroney with Julie Beressi (Radio France Culture) \\ English version, The Sex Workers' Revolt, broadcast ABC Radio National, \\ Earshot, 8 March 2016, 27'24".
}

\begin{abstract}
Editor's Note:
This work has had several incarnations: the original 50-minute French documentary heard on Radio France Culture and Radio Belgium; the French documentary watched with English subtitles provided by the In the Dark organisation; and a shorter (27mins), remixed English version, heard on ABC RN's Earshot. To address these complexities, RadioDoc Review asked former CBC broadcasters Sean Prpick and Maud Beaulieu to review the work from different perspectives: Prpick, as an English-speaking producer, listened to the subtitled French and the English versions; Beaulieu, who is bilingual, evaluated the original French version, using guidelines devised by the RDR Editorial Board. Finally, RDR Editor interviewed producer Eurydice Aroney about the complexities of making a crosscultural work on a politically delicate theme, and its standing as an academic research publication, known as a Non-Traditional Research Output (NTRO).
\end{abstract}

\section{SEAN PRPICK'S REPORT:}

This story, of how hundreds of French sex workers went on strike and occupied five Catholic churches to protest against police abuse and government closure of their workplaces, is compelling indeed and it grabbed me from the very beginning. Even at this point in the 21st century it's unusual to imagine sex workers operating as a militant trade union, as these women did in France back in 1975. The fact that they combined forces with activist priests to achieve their goals is even more amazing, but as the documentary makes clear, it makes perfect sense because of the French clerics' strong identification of the women with Mary Magdalene. Magdalene is the most sympathetic sex worker in the New Testament, who was also a kind of 13th apostle closely aligned with Jesus. I was engaged from the get go, as I think any listener would be.

This is a splendidly original and innovative idea. I vaguely remember this story from my youth, but the idea to go back and update it forty years later is a brilliant one. I had no idea of the many nuances of the original story and its historical significance nearly half a century later. This radio documentary taught me a lot.

I also know from my experience as a radio producer that working with original foreign language material with translation laid on top can be very tricky. One language can get in the way of the other. But this was perfectly blended and the English speakers speaking on behalf of the Francophones mixed beneath them perfectly captured the feeling and emotion of the witnesses to this period, like Maria the veteran sex worker, and good old Père Blanc. 
What a lively, energetic 90-year-old Père Blanc is! He exudes a kind of open-hearted holiness that must make him a poster boy for the current Pope. No judging or condemnation from this guy for prostitutes. Just love and support and willingness to be a shepherd to a very unlikely, motley flock.

I'm very fond of the sex worker Maria, too, who comes across as a no-bullshit survivor, a world-weary cynic who, despite her background and apparent lack of interest in spirituality, has the deepest respect for Blanc.

And my compliments to the producer for recruiting Sydney sex workers to voice the translation for Maria and other French women who show up on tape. What a splendid idea! No doubt because they identified with their French colleagues, they delivered excellent performances and their participation added an extra note of verisimilitude.

The most moving part of the documentary for me was the 2015 trip back to the Lyon church with Père Blanc, where the first protest was staged. Lapsed Catholic that I am, I still fully understand the impact it had on him to learn the chapel had been very appropriately renamed for Mary Magdalene. The astonishment and joy you could hear in his voice was quite remarkable.

While the writing was concise and conversational, it still shows the hand of a producer who did a great deal of research and who had a deep knowledge of the history and context.

What was missing, though, in this English language version, was more of a sense of France in 1975. My understanding is that this was a period of great change and that the French, believe it or not, were a few years behind the English-speaking world in terms of the vast transformations that were happening socially, politically and economically. In a sense, up until the early '70s, France was still in the grip the stuffiness and conformity of the post-war world and the election in 1974 of President Valery Giscard d'Estaing, a moderate, relatively progressive type, opened things up and gave space for new thinking on things like abortion, sex work and much else. Although the sex workers might have had their troubles with cops and other rednecks in their communities, the fact that they got as far as they did and brought about as much change as they did might have something to do with the broader movements afoot in French society, so it would have been nice to hear more about that.

Nothwithstanding, I give high marks to the craft and artistry of this project. It was beautifully mixed and I especially enjoyed the subtle yet distinctive use of the sound of the French streets, plus the clever use of music throughout, which really enhances the story. I also liked the singing of the old protest songs by, I gather, Père Blanc. Nice touch!

Ethically, this project is flawless. It handles the story of the French sex workers with great respect and tenderness and this virtuous circle is expanded further by including their Australian counterparts in the voiceover.

I also am impressed by the treatment of Père Blanc and the portrayal of his enduring moral and spiritual strength, despite his advanced years. In this secular age such sympathetic portrayals of such holy men are rare.

I think re-telling this story is of great public benefit: it tells listeners about an important, historic event of the past that resonates down to the present day.

Overall, throughout this radio documentary, I felt I was in the hands of a mature, expert storyteller at the peak of her powers. 


\section{MAUD BEAULIEU'S REPORT:}

This addresses guidelines devised by RadioDoc Review's editorial board to help in evaluating audio features and documentaries. Scroll down at http://ro.uow.edu.au/rdr/ policies.html

\section{STORYTELLING STRENGTH}

(how compelling is the story, storyline)

This is an important social issue, told mainly through the experience of two credible and likeable characters. The story flows well, with different aspects well connected. e.g. how the strike went from a "women's" issue to a "security" issue.

\section{ORIGINALITY AND INNOVATION}

\section{Good}

\section{AUDIENCE ENGAGEMENT}

(how does it pull audience in and connect with audience)

The choice of extracts in headlines is very strong and pulls you in. Especially the extract about the women appealing to the French President as being president of all citizens, including the president of prostitutes. This appeals to us listeners as citizens.

It builds connection by showing that these women were mostly mothers working to feed their children who launched this protest because of police persecution and fear of losing their children, as opposed to the stereotyped "shameful" prostitutes.

Listeners will be further engaged by hearing how government agencies and/or police decried and prosecuted prostitution while benefiting financially from it.

The main characters (Maria and Père Blanc) are relatable, especially Père Blanc. He sees humour in his position as the parish priest involved in this situation.

\section{RESEARCH AND REPORTING}

(depth, breadth, and accuracy of knowledge accessed)

It is not a 'knowledge' kind of story, so I don't think much research was needed beyond finding the main characters and digging up extracts from past material.

\section{COMPLEXITY OF INFORMATION AND PORTRAYALS} (interplay between content/research and form/audio medium)

There is a good mix of extracts from conversations with main characters, material from archives and commentator Lilian Mathieu to move the story along.

The main irritant: I often found myself wondering who was talking. Main characters Maria and Père Blanc are easy to recognise. But other voices are not always identified and cause confusion.

One suggestion: could have cut the woman in Paris (I think), a mother who goes into prostitution to feed her daughter. She is there to illustrate the fact that the movement spread to other cities, but the point of the mother-prostitute has been illustrated enough already.

It was a difficult choice for the producer, I presume, not ending with what was the real climax in my opinion: the chapel's name in St-Nizier being re-named Chapelle de Marie- 
Madeleine from its original name, Chapelle St-Joseph. I guess they wanted to finish with their core subject, the prostitute voices, but this final clip only repeats what has been said in the documentary. They should have chosen a stronger 'last woman voice'.

\section{EMOTIVENESS AND EMPATHY}

(identification with talent/characters, affect, evokes visceral response)

The people the producer talks to directly (Maria, Père Blanc) are engaging, especially Père Blanc with his sense of humour.

\section{CRAFT AND ARTISTRY}

(use of sound, mix of sound, scripting, pacing)

The pacing is very good, there is time to reflect, with use of the national anthem song and recurring music theme.

The use of sound really makes us feel that we are in that church, or just outside on the street.

There may be a bit too much sound/music early in the documentary, but it levels off after about a third of the way in.

Special effect music is well chosen, particularly around police operation to clear churches.

\section{ETHICAL PRACTICE}

(fair, honest and considerate treatment of topics and talent)

This documentary does not pretend to present a 'balanced' point of view on this event. But we do hear that there was public opposition to the movement.

\section{PUBLIC BENEFIT}

(contribution to store of knowledge)

We hear at the beginning that this story is quite well known in Lyon, but not universally, as shown by the current parish priest who does not seem to know much about it. It is interesting to hear that the French minister responsible for women's affairs did not recognise this event as a women's issue but as a police matter. 


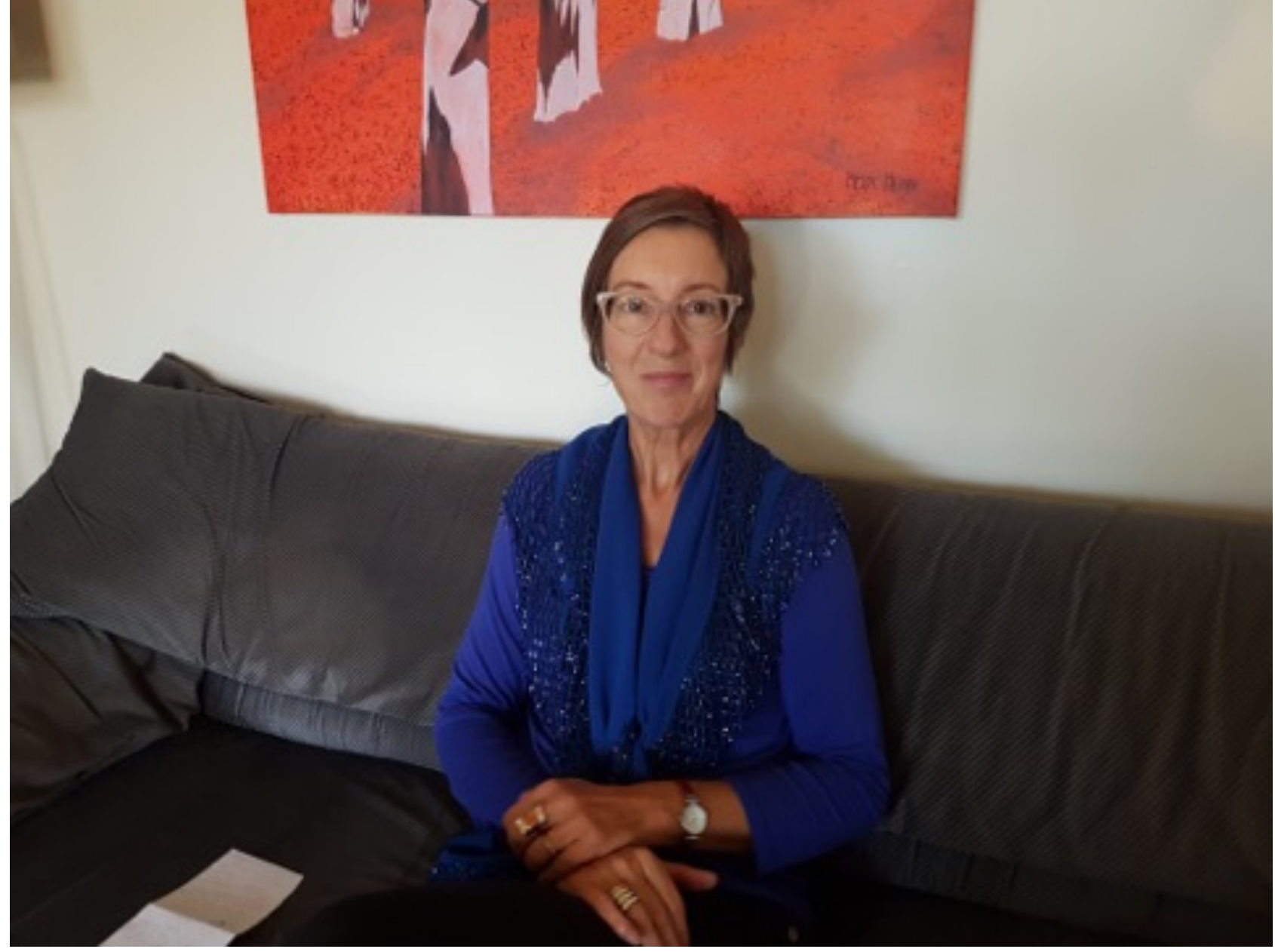

\section{MAUD BEAULIEU:}

Maud Beaulieu was born and raised in what people consider the most French part of the Province of Quebec, the Saguenay region north of Quebec City. She moved to Quebec in her teen years and early twenties, before moving on to McGill University in Montreal to get her MA in political science. She got a second MA in political studies from the College of Europe in Bruges, Belgium. After joining the French division of CBC, Radio-Canada in Regina, Saskatchewan, where she met and married Sean, she rose through the ranks at Rad-Can doing a variety of jobs in journalism and management, before ending her career a few years ago as Managing Editor of all Rad-Can journalism in Western Canada. She currently teaches French in Regina, volunteers at a French publishing house and reads stories to small children at a local French school.

Maud and Sean have two daughters. Lea is a marketing expert at the University of Regina and her sister Zoe is wrapping up a contract teaching ESL in Korea. Zoe plans on getting a grad degree in publishing. 


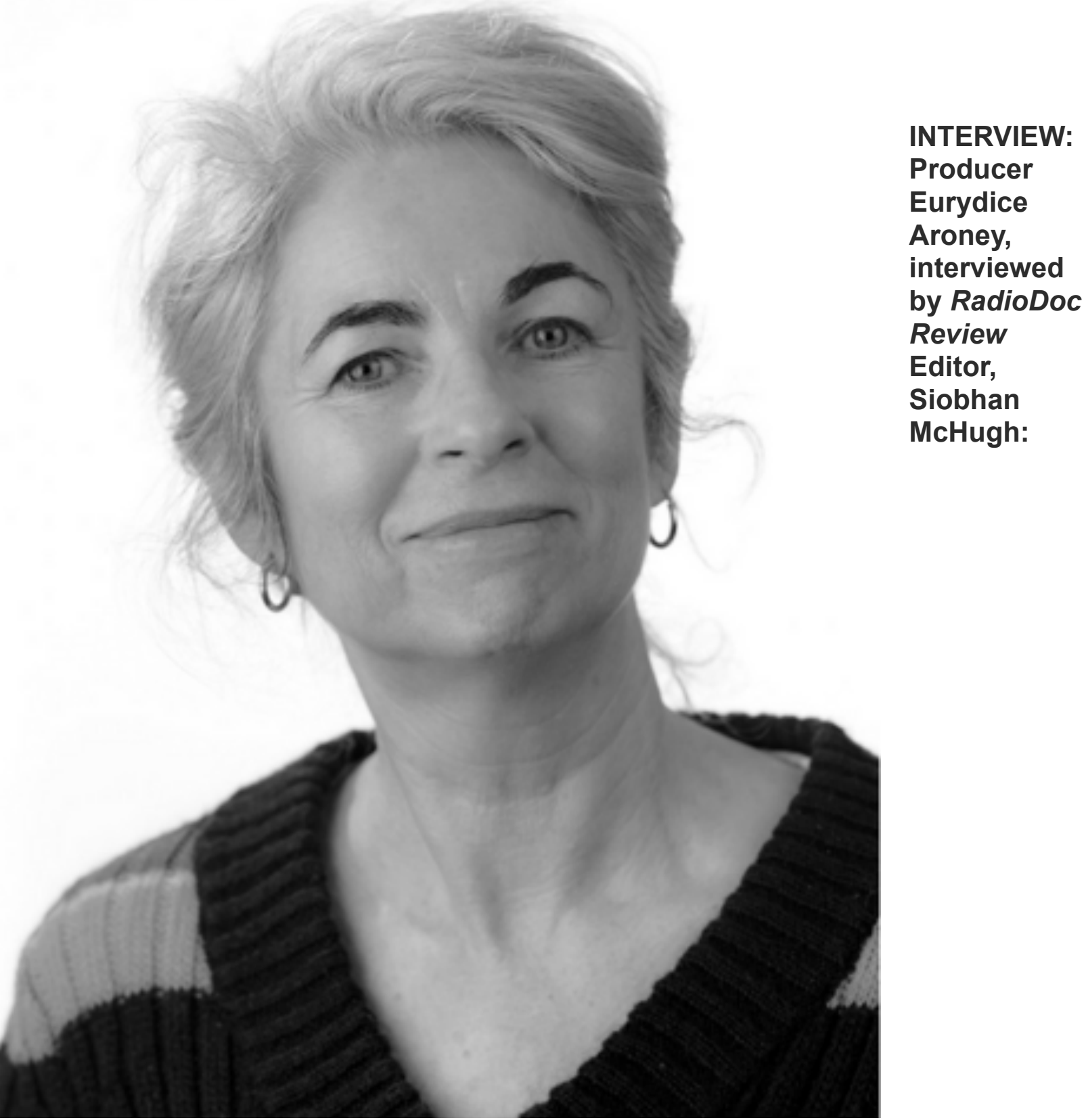

1. How did you address transcultural challenges in making the documentary?

The transcultural challenges of producing a radio show in a language I barely speak were overcome through a combination of funding, resources and team work. In other words, in the large, I depended on others for advice in that quarter. La Revolte was commissioned and partially funded under the "Du Cotes Des Ondes" program, a competitive grant managed by Pascale Tison, Executive Producer of Par Ouï-dire at RTBF [French language Radio and Television in Belgium]. I also received research and some production funding from the University of Technology, Sydney (UTS). UTS also paid my wage during the long period of pre and post-production. The English language version was commissioned by ABC Radio National. Essentially this funding meant I had Frenchspeaking fixers in Lyon, French-speaking translators and editors.

Early on in the process Radio France came on board and provided work in-kind. Radio France EP Irène Omélianenko was instrumental in supporting the project and identified the existence of [a related] archive after being approached by acclaimed feature producer and writer Kaye Mortley, an Australian expatriate and long-term resident of France. I contacted Kaye out of the blue as a relative stranger - but she responded immediately and we corresponded about the production of La Revolte. 
I depended on Kaye for advice. Without her involvement - all unpaid - the program would not have been made.

I had worked on an initial edit with a French-speaking journalist in Sydney but when I took that edit to France for the mix, Kaye rightly kept saying 'where are the women?'. And so we reassembled the edit by returning to recordings that I had made in Lyon and using more of the archives. All Radio France archives are available to review free online through the Institut National de l'Audiovisuel (INA), which is a repository of all French radio and television audiovisual archives. So we could just pull up the files and listen (and watch) perfectly preserved radio news bulletins, radio current affairs stories plus feature material. Radio France then paid a fee to INA to use the radio archives.

Producing the English language edit - at half the original length - was less successful in some ways. The texture and range of French language 'voices' was lost because of translation overlays and I had to add my narration that interrupted the flow of the original piece. If this had been film, I could have just had subtitles and the sound design would have remained intact.

The strangest thing was that I only realised what the characters were saying in full when I 'watched' the French version on Vimeo with English subtitles, produced by the In The Dark organisation. Because we didn't have time to do a translation of the final mix scripts I had mixed it not really knowing what people were saying. I had to rely on other people's interpretations - including the program's sound engineer, Pierre Devalet in Brussels - as we mixed it, to provide summaries of each grab. So when I 'saw' it with English subtitles I 'heard' dialogue that I hadn't known was there. It was like hearing it for the first time. I wasn't disappointed in the final content although I did hear things that perhaps I would have made different choices about if I had understood the language.

\section{Sex Workers as Subjects}

How much did the Australian sex workers who did voiceover identify with the experiences of their French counterparts through becoming participants? How did you mediate this?

Using Australian sex workers to play the French sex workers in the English version was an attempt to retain the 'authenticity' of the sex worker voices and to increase its appeal to the sex worker community and the general audiences. This idea came from a sex worker friend and activist Elena Jefferies, former President of Scarlet Alliance in Australia. Her input was crucial to me having access to and gaining the trust of sex workers in France and Australia. The Australian sex workers really got on board with the project and identified with the story.

In many ways sex workers across the world suffer from similar human rights abuses and discriminatory laws. The poor working conditions, the discrimination and abuse that sex workers experience persists in most parts of the world and so for sex workers, and for myself as someone having been part of the sex workers' rights movement since the 1980s, the issues were already familiar. When I was a young sex worker rights activist in the 1980s, we regularly visited brothels as part of outreach. We were spreading the news about safe sex but at the same time we drew on the story of the French strike and church occupations as a way of politicising and motivating workers to become part of 
the wider rights movement. I've also published articles about what I found in The Conversation and been interviewed by sex worker bloggers about the research, given presentations about my research at sex worker events and conferences and obviously the radio shows are central to spreading the message: that sex worker rights are a human rights issue.

\section{Academic Data as a NTRO (Non-Traditional Research Output)}

How is this documentary the equivalent of a scholarly work of research? What are the pros and cons of presenting academic research in this form?

Suffice to say, without a French language team and additional funding and resources from UTS, the project would not have been possible. UTS recognised that the project was original research produced in a non-traditional format and so were able to support it. A project like this is beyond the funding capacity of most public broadcasters and sometimes it felt way beyond my capacity as well! It was touch and go sometimes resources were invested on the premise that it would be made and then it was difficult to get the piece commissioned and so that was stressful. But I was persistent and UTS were generous in awarding workload points for the French version as a non-traditional research outcome [legitimising its status as a scholarly publication]. I have since had an academic paper about the strike accepted for publication in a prestigious A-grade scholarly journal, so I'm pretty happy.

I think that if audio [works] are to be counted as non-traditional research then in some ways they should demonstrate a deeper degree of research or experimentation than what is possible in an ordinary commissioning process. Since coming to UTS I have always attempted to produce radio that is edgy, experimental, involves a deep investigation etcetera, and in recent years I've been able to count it in my workload. The extra 'edge' if you like in these programs was the difficulty in having it commissioned. Sex work is a saleable subject until it comes to sex workers having political agency; then suddenly commissioners lose all interest. I've been recording and producing sex worker stories for over twenty years but La Revolte was the most difficult to get made. It's as if sex workers being part of a social movement for change is too incongruous an idea. There are no popular discourses on sex worker agency/ politicisation for a general audience to tap into and this means that you're selling something that doesn't make sense to people. This then for me differentiates these programs from the usual [media] offerings about sex workers. The global social movement for sex workers rights has been around for around the same length of time as the contemporary gay movement. In France in the 1970s, gay men worked their beats on the exact same streets as the sex workers. My research showed that gay men supported the French strike, handing out pamphlets on the street to a supportive public outside the church of St Nizier in Lyon. Now, forty years later, there is same sex marriage - in France and Australia at least - but in contrast, sex worker rights are going backwards in most of the world.

We as academics are privileged to be working with a level of support not available to most other broadcasters and that needs to be reflected in the work. But then again, I know that not all Australian universities are as supportive of non-traditional research outputs to the degree that UTS is, and it is difficult for journalists within most universities to confidently set out to produce [crafted audio] work that will count as much as traditional scholarly research. In fact I think that this process - even with this outcome - has shown me that publishing academic papers is easier than making a radio program at this point of my career and I will think twice about doing it again. 
Making the show was incredibly rewarding in terms of its impact and community reach. It went to air across France and Belgium on the fortieth anniversary of the strike and so it was perfect timing (deliberately so). The day of the occupation, June 2 nd, has been commemorated by sex workers as "International Whores Day" for the last forty years so the show got a lot of traction in the sex worker communities in the US, Europe and Australia. I was able to tweet the archival discoveries - the audio links, documents, photos etcetera - direct to my twitter followers in the sex worker rights movement and these were re-tweeted by accounts like @whoresofYore, which has over 100,000 followers and growing. Today, for instance, I got an email from a producer of a new sex worker activist podcast in the US titled, "The Oldest Profession", about sex workers in history. They wrote that hearing my program partly inspired what in my opinion is their very funny and inspired podcast series. So 'the tail' is long.

\section{FULLCREDITS:}

La Revolte des Prostituees/The Revolt of the Prostitutes (2015)

D: 50'35"

Broadcast June 2015 by Radio France Culture and Radio Belgium.

Produced by Eurydice Aroney with Julie Beressi (Radio France Culture)

https://www.franceculture.fr/emissions/sur-les-docks-14-15/la-revolte-des-prostituees-de-saint-nizier

Sound recording: Pierre Devalet (RTBF) and Alain Joubert (France Culture)

Commissioned by "Du Coté des Ondes" (On the side of the waves) fund, a co-production of RTBF with Pascale Tison, and France Culture with Irène Omelianenko, with the support of the University of Technology, Sydney.

Text from The Divided pub Editions de Minuit, authors 'Barbara' and Christine de Coninck, and performed by Juliette Roudet.

Original Music Stuart Brown. Research and production assistance from Alexis Caraco, Nicole Gooch, Albert Lecoanet, Tom Morton and the exceptional contribution of Kaye Mortley. Listen in French along with English subtitles at https://vimeo.com/139457788

See ABC RN Earshot page for full credits of English language version, The Sex Workers' Revolt (2016, 27mins).

http://www.abc.net.au/radionational/programs/earshot/the-sex-workers-revolt/7163548

Transcripts of both programs: https://www.academia.edu/12300698/

La_Revolte_des_Prostituees_-

_English_and_French_language_transcripts_of_the_radio_documentary_Sex_worker_revolts_h istory_ 